\title{
UJI EFEKTIVITAS PERTUMBUHAN Lactobacillus casei PADA MEDIA UMBI GANYONG MERAH DAN GANYONG PUTIH
}

\author{
1Zahra Aptari, ${ }^{2}$ Irka Vil'um Yurdillia, ${ }^{3}$ Regina Abiputri Siswanto \\ zahraaptari.2018@student.uny.ac.id, irkavilum.2018@student.uny.ac.id, \\ reginaabiputri.2019@student.uny.ac.id \\ Jurusan Pendidikan Biologi, Fakultas Matematika dan Ilmu Pengetahuan Alam \\ Universitas Negeri Yogyakarta
}

\begin{abstract}
ABSTRAK
Salah satu media tumbuh bakteri yang sering digunakan dalam laboratorium adalah Nutrient Agar (NA). Namun, harga dari media pertumbuhan bakteri ini relatif mahal. Mahalnya harga media serta melimpahnya sumber alam yang belum dimanfaatkan oleh masyarakat mendorong peneliti untuk menemukan media alternatif baru dari bahan-bahan sederhana yang mudah didapatkan. Salah satu bahan yang mengandung nutrisi yang baik jika digunakan sebagai media adalah umbi karena kandungan karbohidratnya yang tinggi. Penelitian ini menggunakan media Nutrient Agar sebagai kontrol serta dua jenis umbi ganyong yaitu varietas ganyong putih dan ganyong merah. Penelitian ini merupakan penelitian eksperimental untuk mengetahui bagaimana efektivitas dan karakteristik umbi ganyong sebagai media pertumbuhan bakteri, mengetahui varieatas umbi ganyong yang paling efektif, serta mengetahui berapa konsentrasi bubuk ganyong paling efektif untuk tumbuh bakteri yang mana dalam penelitian ini menggunakan tiga variasi konsentrasi bubuk umbi ganyong yaitu sebanyak 10 gram, 20 gram, dan 30 gram

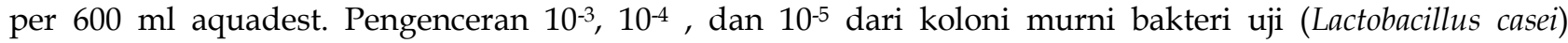
ditanam pada masing-masing media sebanyak dua ulangan dengan teknik spread, kemudian diinkubasi pada suhu $37^{\circ} \mathrm{C}$ dan diamati setiap 24 jam selama tiga hari. Hasil penelitian menunjukkan bahwa bakteri dapat tumbuh pada media yang terbuat dari umbi ganyong dengan jumlah koloni bakteri tertinggi sebanyak 9,5.103 $\mathrm{CFU} / \mathrm{ml}$ pada media ganyong putih dengan konsentrasi bubuk ganyong putih sebesar 20 gr/600 ml. Hal ini membuktikan bahwa umbi ganyong putih jauh lebih efektif sebagai media tumbuh bakteri dibanding dengan umbi ganyong merah.
\end{abstract}

Kata kunci: media alternatif, media tumbuh bakteri, Nutrient Agar, umbi ganyong

\begin{abstract}
One of the bacteria growing media that is often used in laboratories is Nutrient Agar (NA). However, the price of this bacterial growth medium is relatively expensive. The high price of media and the abundance of untapped natural resources have encouraged researchers to find new alternative media from simple ingredients. Tubers contain high carbohydrate content so they have potential to be used as the medium. This study used Nutrient Agar as a control as well as two varieties of canna tubers (Umbi Ganyong), namely white canna and red canna. This research is an experimental study to determine the effectiveness and characteristics of canna tubers as a medium for bacterial growth, which in this study used three variations of the concentration of canna tuber powder (10, 20,30) grams per $600 \mathrm{ml}$ aquadest. The results showed that bacteria can grow on media made of $20 \mathrm{gr} / 600 \mathrm{ml}$ white canna tubers with the highest number of bacterial colonies of 9,5.103 $\mathrm{CFU} / \mathrm{ml}$. This proves that white canna tubers are much more effective as a medium for growing bacteria compared to red canna tubers.
\end{abstract}

Keyword: alternative media, bacterial growth media, Nutrient Agar, Canna edulis tuber

\section{PENDAHULUAN}

Media merupakan bahan yang dapat digunakan sebagai tempat pertumbuhan mikroorganisme seperti bakteri dan jamur. Bakteri adalah salah satu kelompok mikroorganisme yang keberadaannya yang sangat melimpah di lingkungan. Berdasarkan manfaatnya, terdapat dua jenis bakteri yaitu bakteri yang menguntungkan dan bakteri yang 
merugikan. Baik bakteri menguntungkan dan merugikan, keduanya sama-sama bermanfaat terutama untuk kegiatan praktikum sehingga bakteri banyak dibiakkan dalam suatu media. Contoh bakteri menguntungkan adalah Lactobacillus casei yang merupakan salah satu spesies bakteri asam laktat (Margawani, 1995). Bakteri asam laktat umumnya hidup pada kisaran suhu 15$45^{\circ} \mathrm{C}$, sedangkan suhu optimumnya adalah 30-37 ${ }^{\circ} \mathrm{C}$ (Fonden et al. 2000; Hutkins, 2006). Beberapa jenis mikroorganisme dapat tumbuh baik pada media yang hanya mengandung bahan-bahan sederhana seperti gula. Suatu media dapat menumbuhkan mikroorganisme dengan baik bila memenuhi persyaratan antara lain kelembapan yang cukup, pH yang sesuai, kadar oksigen baik, media steril dan media mengandung nutrisi yang mudah digunakan mikroorganisme (Dwidjoseputro, 2005). Salah satu media tumbuh yang sering digunakan dalam laboratorium adalah Nutrient Agar (NA). Namun, harga dari media pertumbuhan bakteri ini relatif mahal. Harga media pertumbuhan bakteri instan rata-rata mencapai Rp. 500.000 hingga Rp. 1.500 .000 (Anisah, 2015).

Salah satu bahan yang mengandung nutrisi dan baik jika digunakan sebagai media adalah umbi karena kandungan karbohidratnya yang tinggi. Umbi yang belum banyak diketahui oleh masyarakat luas sehingga pemanfaatannya masih terbatas adalah umbi ganyong. Di Yogyakarta sendiri, umbi ganyong keberadaannya melimpah sehingga masuk dalam salah satu hasil pertanian. Khusus di Kabupaten Gunung Kidul, hampir 80\% petani menanam ganyong di lahan pertanian mereka. Dalam masa panen bulan Agustus-September dan rata-rata menghasilkan sekitar 1 ton ganyong segar sekali panen (Susanti, 2015:182).

\section{Tanaman ganyong (Canna edulis)} termasuk famili Cannaceae, genus Canna dari kelompok ubi-ubian potensial. Tumbuhan ini berbentuk herba berumpun dan bersifat perennial (Segeren dan Maas, 1971). Di Indonesia, terdapat dua varietas umbi ganyong yaitu umbi ganyong merah dan umbi ganyong putih. Umbi ganyong merah berwarna merah atau ungu dan umbi ganyong putih berwarna cokelat (Mutiningsih dan Suyanti, 2011). Ganyong putih adalah salah satu jenis varietas ganyong yang umumnya dimanfaatkan untuk diambil patinya, sedangkan ganyong merah dimasak dengan cara direbus untuk dikonsumsi (Balai Besar Penelitian dan Pengembangan Bioteknologi dan Sumberdaya Genetik Pertanian, 2010).

Pati ganyong merah dan ganyong putih mempunyai perbedaan komposisi makronutrien dan mikronutrien. Komponen protein, lemak, pati dan amilosa ganyong merah berbeda nyata terhadap ganyong putih sedangkan komponen amilopektin dan abu keduanya tidak berbeda. Pati ganyong merah mempunyai kandungan protein dan lemak lebih tinggi sebesar 62,2\% dan 94,72\% daripada ganyong putih, sedangkan kandungan pati dan amilosa dari pati ganyong merah lebih rendah sebesar $1,61 \%$ dan $4,45 \%$ daripada ganyong putih. Komponen mikronutrien Fe dan Ca kedua jenis umbi ganyong tidak berbeda nyata sedangkan komponen $\mathrm{P}$ dan vitamin $\mathrm{C}$ 
berbeda nyata. Pati ganyong merah mempunyai kandungan vitamin $\mathrm{C}$ lebih tinggi sebesar $10,55 \%$ daripada ganyong putih, sedangkan kandungan $\mathrm{P}$ pati ganyong merah lebih rendah sebesar $36,53 \%$ dari ganyong putih. Perbedaan komposisi makronutrien dan mikronutrein antara ganyong merah dan ganyong putih disebabkan oleh perbedaan varietas antara keduanya. (Ema Damayanti, 2007). Sedangkan kandungan dari media Nutrient Agar adalah ekstrak daging, peptone, agar sebagai pemadat, dan yeast extract yang tertulis dalam kemasan merk OXOID.

Berdasarkan uraian tersebut, mahalnya harga media serta melimpahnya sumber alam yang belum dimanfaatkan oleh masyarakat mendorong peneliti untuk menemukan media alternatif baru dari umbi ganyong. Melihat segala permasalahan tersebut, maka dilakukanlah penelitian yang bertujuan untuk mengetahui keefektifan pertumbuhan bakteri Lactobacillus casei pada media yang terbuat dari umbi ganyong dan karakteristik media umbi ganyong yang dihasilkan, sekaligus membandingkan jenis ganyong (ganyong merah atau ganyong putih) manakah dan pada konsentrasi berapakah umbi ganyong paling efektif digunakan sebagai bahan media tumbuh bakteri.

\section{METODOLOGI PENELITIAN}

Jenis penelitian yang digunakan adalah penelitian eksperimen yaitu membuat media pertumbuhan bakteri Lactobacillus casei dari umbi ganyong merah dan ganyong putih dan membandingkan kedua media tersebut, kemudian menguji pengaruhnya terhadap pertumbuhan bakteri uji dengan menggunakan metode TPC (Total Plate Count).

Penelitian ini dilaksanakan di Laboratorium Mikrobiologi Fakultas Matematika dan Ilmu Pengetahuan Alam Universitas Negeri Yogyakarta pada bulan Agustus 2020. Variabel bebas dalam penelitian ini adalah jenis ganyong (ganyong merah dan ganyong putih), kadar ekstrak ganyong pada media (10 gram, 20 gram, 30 gram), pengenceran bakteri $\left(10^{-3}, 10^{-4}, 10^{-5}\right)$. Variabel terikat dalam penelitian ini adalah jumlah bakteri uji yang tumbuh pada masing-masing media. Sedangkan variabel kontrolnya adalah jenis bakteri uji, suhu dan lama penyimpanan umbi ganyong. Alat yang digunakan dalam penelitian ini adalah pisau, oven, parutan, gelas ukur, petridish, tip dan mikropipet, pipet, drigalsky, colony counter, plastik warp, label, autoclave, magnetic stirrer dan tabung reaksi. Sedangkan bahan-bahan yang digunakan adalah ganyong merah, ganyong putih, isolat murni bakteri Lactobacillus casei, aquadest, agar swallow, gula, dan bubuk Nutrient Agar. Prosedur penelitian adalah sebagai berikut :

1. Pembuatan Ekstrak Umbi Ganyong dan Media

Satu kilogram umbi ganyong merah dikupas dan cuci kemudian diparut dan diambil airnya. Air hasil perasan diendapkan semalam sehingga dihasilkan tepung pati ganyong. Hasil perasan umbi ganyong dijemur dibawah sinar matahari satu hari sampai kering. Setelah kering hasil parutan umbi ganyong di oven $80^{\circ} \mathrm{C}$ selama 15 menit. Setelah itu dihaluskan dan disaring sampai didapatkan serbuk ganyong yang halus. Setelah halus 
disimpan ke dalam aluminium foil. Aluminium foil bisa dijemur dibawah sinar matahari agar tidak lembab. Kemudian tiap ganyong diambil sebanyak 10 gram, 20 gram, 30 gram (masingmasing 3 kali). Masing-masing bubuk umbi yang didapat dilarutkan dalam 600 $\mathrm{ml}$ aquadest. Gula ditambahkan pada masing-masing larutan sebanyak 10 gram gula. Kemudian ditambah 9 gram agar (swallow). Larutan media ini di magnetic stirrer hingga mendidih. Larutan media didinginkan kemudian dituang pada petridish dan diberi label. Media pada petridish dibiarkan memadat kemudian diautoclave selama 15 menit dengan suhu $121^{\circ} \mathrm{C}$. Hal yang sama dilakukan untuk pembuatan media dengan umbi ganyong putih. Ulangan dibuat sebanyak 2 kali untuk masing-masing pengenceran $10^{-3}$, $10^{-4}, 10^{-5}$. Jadi jumlah media yang dibuat adalah 36 media (18 media dari ganyong merah dan 18 media dari ganyong putih).

2. Pembiakkan Mikroba

Bakteri dibiakkan terlebih dahulu dengan cara mengambil bakteri dari biakan murni Lactobacillus casei mikropipet, dan dan di shake dengan media Natrium Broth. Pencampuran dilakukan di 3 tabung reaksi. Kemudian masing-masing biakan bakteri Lactobacillus casei diinkubasi selama $1 \times 24$ jam dengan suhu ruang di shaker.

\section{Pengkulturan Bakteri Lactobacillus casei pada Media}

Isolat murni bakteri Lactobacillus casei diambil sebanyak 0,1 $\mathrm{ml}$ dengan mikropipet kemudian diencerkan sebanyak $10^{-3}, 10^{-4}, 10^{-5}$, kemudian masingmasing pengenceran diambil $0,1 \mathrm{ml}$ dan dituangkan pada media berbeda. Lalu diratakan dengan drigalsky. Petridish diwarp dan diinkubasi terbalik dalam inkubator dengan suhu $37^{\circ} \mathrm{C}$ untuk masing-masing pengenceran dibuat 2 kali ulangan.

\section{Teknik Analisa Data}

Analisa data yang digunakan adalah dengan menghitung jumlah bakteri yang tumbuh pada media. Metode perhitungan jumlah bakteri yang tumbuh dengan TPC (Total Plate Count) secara langsung pada colony counter. Jumlah total bakteri dicari dengan syarat: menghitung jumlah koloni pada masing-masing petridish yang tumbuh pada permukaan agar, jumlah koloni tiap petridish adalah 30-300 koloni, jika tidak ada yang memenuhi syarat dipilih yang jumlahnya mendekati 30, tidak ada koloni yang menutup lebih besar dari setengah luas petridish (spreader), perbandingan jumlah bakteri dan hasil penegenceran berturut-turut antara pengenceran yang lebih besar dengan pengenceran sebelumnya jika sama atau lebih kecil dari dua maka jumlah bakteri merupakan hasil rerata dari dua pengenceran tersebut. Namun jika lebih besar dari 2 maka yang dipakai adalah jumlah bakteri dari pengenceran sebelumnya. Penghitungan jumlah koloni bakteri yang tumbuh dilakukan selama 3 hari dalam rentang waktu 24 jam.

\section{HASIL DAN PEMBAHASAN}

Pembuatan media umbi ganyong dilakukan dengan prosedur sama dengan membuat media bakteri lain seperti media Nutrient Agar yang dalam penelitian ini sebagai kontrol. Umbi ganyong yang digunakan mengalami perlakuan sama dalam hal penyimpanannya yaitu selama 
sepuluh hari pada suhu ruang. Hal ini dikarenakan karbohidrat dalam umbi berpotensi mengalami perubahan jumlah kadar gula pereduksi yaitu antara 0,096 $0,109 \%$ pada penyimpanan 8 hari (Kusdibyo, 2004). Sehingga jika ganyong disimpan dengan lama penyimpanan berbeda akan mengalami penambahan gula pereduksi berbeda dan akan mempengaruhi hasil penelitian. Karakteristik media umbi ganyong yang didapat adalah media dengan umbi ganyong merah kurang transparan sehingga dalam pengamatan koloni bakteri yang tumbuh sulit diamati pada colony

counter.
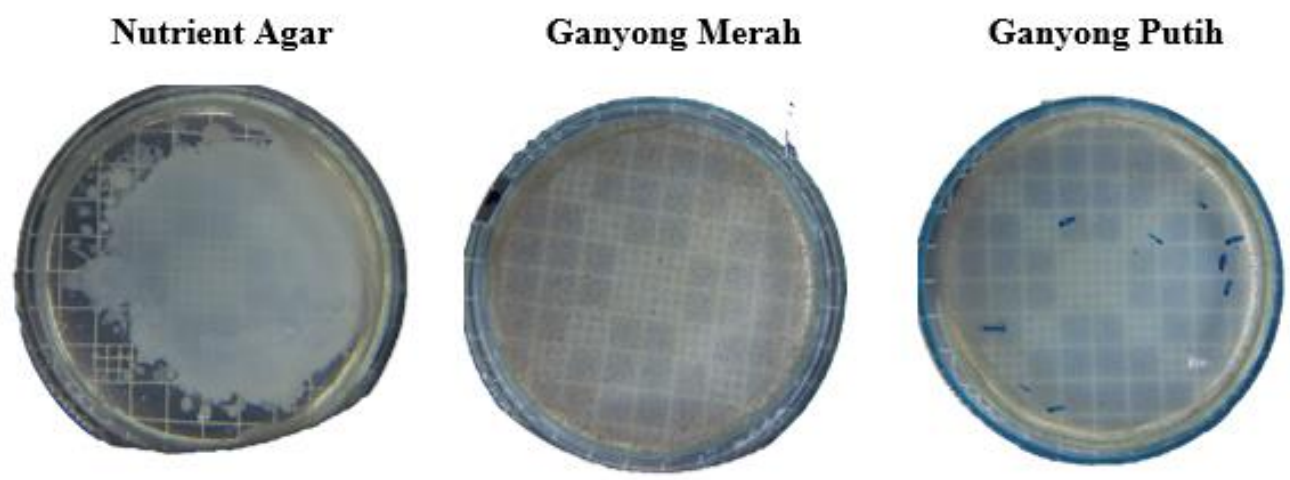

Gambar 1. Hasil pembuatan media dan pertumbuhan koloni bakteri Lactobacillus casei pada masing-masing media.

\section{Sumber: diolah dari data primer}

Pengamatan bakteri yang tumbuh pada media ini dilakukan pada alas yang gelap agar bakteri terlihat jelas. Selain itu, bubuk umbi tidak terhomogenkan dengan baik sehingga membuat media terlihat keruh. Media dari umbi ganyong ini, sama awetnya dengan media NA terbukti setelah lebih dari 6 hari penyimpanan, media umbi ganyong masih dalam keadaan baik-baik saja atau tidak rusak.

Berdasarkan penelitian, dapat diketahui bahwa koloni bakteri dapat tumbuh di media dengan sumber karbohidratnya berupa umbi ganyong. Menurut Slamet (1998) jumlah karbohidrat pada umbi ganyong adalah 18,4 gram per 100 gram. Adanya bakteri yang tumbuh ini juga membuktikan bahwa lingkungan media seperti $\mathrm{pH}$ dan nutrisi media umbi ganyong sudah cukup untuk bakteri uji yaitu bakteri Lactobacillus casei untuk melakukan metabolisme dalam pertumbuhannya. Jumlah bakteri yang tumbuh dari media NA sebagai kontrol, umbi ganyong merah, dan umbi ganyong putih dapat dilihat dari tabel di bawah ini. 
Tabel 1. Hasil pertumbuhan bakteri Lactobacillus casei (cfu/ml)

\begin{tabular}{cccccccc}
\hline & Kontrol & \multicolumn{2}{c}{ 10 gram } & \multicolumn{2}{c}{ 20 gram } & \multicolumn{2}{c}{30 gram } \\
\cline { 2 - 7 } & NA & GM & GP & GM & GP & GM & GP \\
\hline Hari 1 & $3.10^{3}$ & 0 & 0 & 0 & $2,25.10^{3}$ & $0,2510^{3}$ & 0 \\
Hari 2 & $3,5.10^{3}$ & 0 & $0,88.10^{3}$ & $0,25.10^{3}$ & $7.10^{3}$ & $0,5.10^{3}$ & 0 \\
Hari 3 & $3,5.10^{3}$ & 0 & $1.10^{3}$ & $0,25.10^{3}$ & $9,5.10^{3}$ & $0,5.10^{3}$ & $2.10^{3}$
\end{tabular}

Keterangan: (NA) Nutrient Agar, (GM) Ganyong merah, (GP) Ganyong putih

Sumber: diolah dari data primer

Dari tabel diatas, diketahui bahwa pada hari pertama bakteri sudah mulai tumbuh pada beberapa media mulai dari yang terbanyak yaitu media NA, media ganyong putih dengan konsentrasi bubuk ganyong 20 gram, dan media ganyong merah dengan konsentrasi bubuk ganyong 30 gram, dengan jumlah bakteri berurutan adalah $3.10^{3} \mathrm{CFU} / \mathrm{ml}, 2,25.10^{3} \mathrm{CFU} / \mathrm{ml}$ dan $0,2510^{3} \mathrm{CFU} / \mathrm{ml}$. Pada hari kedua, pada beberapa media seperti ganyong putih 10 gram dan ganyong merah 20 gram, mulai tumbuh bakteri dengan jumlah bakteri pada masing-masing media tersebut secara berurutan adalah $0,88 \cdot 10^{3}$ $\mathrm{CFU} / \mathrm{ml}$ dan $0,25 \cdot 10^{3} \mathrm{CFU} / \mathrm{ml}$. Jumlah bakteri yang sudah tumbuh pada hari pertama, bertambah dengan pertambahan jumlah tertinggi sebesar 4,75 CFU/ml terjadi pada ganyong putih konsentrasi bubuk ganyong 20 gram. Pada hari ketiga pengamatan, rata-rata jumlah bakteri pada media tidak berubah. Pada ganyong putih konsentrasi 30 gram, bakteri mulai tumbuh dengan jumlah $2.10^{3} \mathrm{CFU} / \mathrm{ml}$. Meskipun bakteri pada media tersebut baru tumbuh pada hari ketiga, namun jumlah bakteri yang tumbuh melebihi jumlah bakteri pada media ganyong merah konsentrasi 30 gram yang mana pada media ini koloni bakteri sudah muncul sejak hari pertama pengamatan. Hal ini terjadi karena pertumbuhan bakteri tidak hanya dipengaruhi oleh nutrisi tumbuh namun juga bagaimana kondisi lingkungan media. Sehingga waktu tumbuh bakteri berbeda.

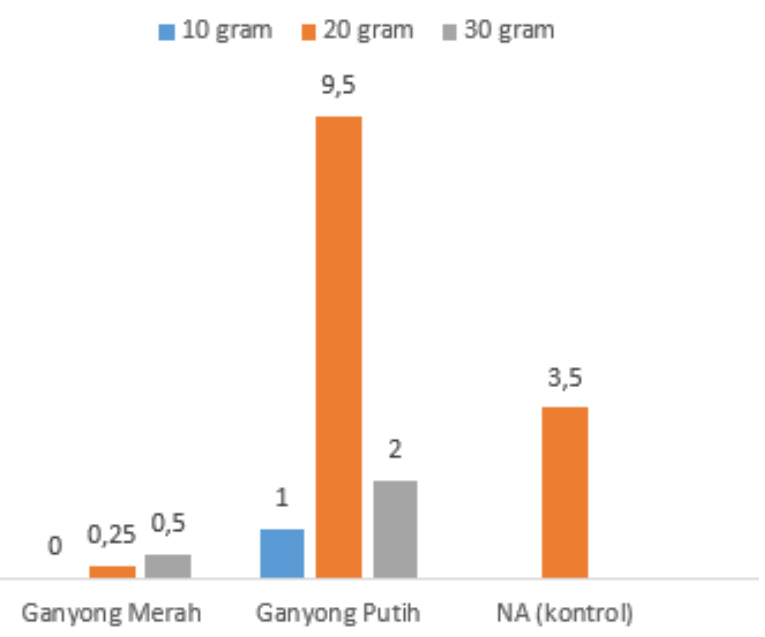

Gambar 2. Diagram jumlah akhir koloni bakteri Lactobacillus casei (CFU/ml)

Sumber: diolah dari data primer 
Pada media ganyong merah 10 gram, tidak terdapat bakteri yang tumbuh yang dapat disebabkan oleh terlalu rendahnya kandungan karbohidrat sehingga bakteri tidak mampu bermetabolisme untuk tumbuh dan berkembang secara optimal. Hasil akhir perhitungan bakteri yang dihitung pada hari ketiga sebagai hari terakhir pengamatan dapat dilihat pada diagram batang yang tercantum pada gambar 2.

Dari pertambahan jumlah koloni bakteri per hari yang diamati, kecepatan tumbuh bakteri tertinggi dan jumlah bakteri terbanyak adalah pada media ganyong putih dengan konsentrasi 20 gram. Hal ini terjadi karena kandungan pati dan amilosa dari pati ganyong putih lebih tinggi sebesar $1,61 \%$ dan $4,45 \%$ daripada ganyong merah (Damayanti, 2007). Kandungan pati pada media ganyong juga lebih tinggi dari media NA karena sumber karbohidrat utama dari NA hanya dari ekstrak daging yang lebih banyak mengandung protein. Amilosa merupakan polisakarida dengan glukosa sebagai monomernya dan dimanfaatkan sebagai sumber bakteri untuk tumbuh.

Pada media ganyong juga terdapat mikronutrient yang lebih lengkap dibandingkan dengan media NA. Jumlah bakteri pada media ganyong putih ini juga melebihi jumlah bakteri yang tumbuh pada media NA yang sudah teruji klinis sebagai media tumbuh bakteri dikarenakan pada media NA, koloni yang tumbuh umumnya menyebar (spreader) dan berukuran besar. Menurut Anisah (2015) bentuk koloni seperti ini akan mempengaruhi jumlah populasi bakteri karena koloni bakteri berkumpul menjadi satu. Dengan begitu, dapat diketahui bahwa media yang paling efektif untuk pertumbuhan bakteri terutama Lactobacillus casei adalah media ganyong putih dengan konsentrasi bubuk ganyong sebesar 20 gram yang memiliki kandungan pati yang lebih tinggi dibandingkan dengan media ganyong merah dan media NA.

\section{KESIMPULAN DAN SARAN}

Berdasarkan hasil analisis data dan pembahasan dapat disimpulkan bahwa bakteri dapat tumbuh pada media yang terbuat dari umbi ganyong. Varietas umbi ganyong putih lebih efektif digunakan sebagai media tumbuh bakteri terutama pada konsentrasi $20 \mathrm{~g} / 600 \mathrm{ml}$ aquadest.

Saran dari penelitian ini adalah menghaluskan bubuk ganyong hingga sangat halus sebelum digunakan sebagai bahan media, menggunakan alas lebih gelap untuk mengamati pertumbuhan bakteri pada media umbi ganyong. Selain itu, perlu diadakan penelitian lebih lanjut tentang media alternatif pertumbuhan bakteri dari umbi ganyong menggunakan bakteri berbeda maupun menggunakan spesies fungi.

\section{UCAPAN TERIMAKASIH}

Diucapkan terimakasih kepada semua pihak yang telah berkontribusi dalam penelitian ini, terutama Fakultas Matematika dan Ilmu Pengetahuan Alam UNY yang mendanai penelitian ini serta Ibu Lili Sugiyarto, M.Si selaku pembimbing penelitian, sehingga penelitian ini dapat berjalan dan terlaksana dengan baik. 


\section{DAFTAR PUSTAKA}

Anisah, R. (2015). Media alternatif untuk pertumbuhan bakteri menggunakan sumber karbohidrat yang berbeda. Seminar Nasional Pendidikan Biologi Fakultas Keguruan dan Ilmu Pendidikan Universitas Muhammadiyah Surakarta, 855-860.

Damayanti, E. (2007). Komposisi nutrien dan kandungan senyawa bioaktif pati ganyong (Canna edulis Ker.) kultivar lokal Gunungkidul. Yogyakarta: UPT BPPTK LIPI.

Dwidjoseputro. (2005). Dasar-dasar mikrobiologi. Jakarta: Djambatan.

Fonden, R., Mogensen, G., Tanaka, R., \& Salminen, S. (2000). Effect of culture containing diary products on intestinal microflora, human nutrition and health - current knowledge and future perspectives. International Dairy Federation Bulletin, 352.

Hutkins, R.W. (2006). Microbiology and technology of fermented foods. Oxford: Blackwell Publishing.

Kusdibyo \& Asandhi, A.A. (2004). Waktu panen dan penyimpanan pasca panen untuk mempertahankan mutu umbi kentang olahan. Jurnal Ilmu Pertanian, 11 (1), 51 - 62.

Margawani, K. R. (1995). Lactobacillus casei galur shirota (bakteri yakult), peranannya dalam kesehatan manusia. Buletin Teknik dan Industri Pangan, 6 (2), 93-99.

Murtiningsih dan Suyanti. (2011). Membuat tepung umbi dan variasi olahannya. Jakarta: Agro Media Pustaka.

Segeren, W. \& P.J.M. Maas. (1971). The genus canna in northern south amerika. Acta Bot. Neerl., 20 (6), 663680.

Slamet, D.S. \& Ignatus, T. (1980). Komposisi zat gizi makanan indonesia. Jurnal Penelitian Gizi dan Makanan (ISSN: 0125-96950125- 9695. EISSN: 2338-3453).

Susanti, A. (2015). Strategi membangun kemitraan dalam pemberdayaan masyarakat. Proseding seminar Nasional Hasil Pengabdian Kepada Masyarakat. Yogyakarta: Lembaga Pengabdian kepada Masyarakat Universitas Ahmad Dahlan. 